\title{
Molecular detection of Renibacterium salmoninarum in rainbow trout (Oncorhynchus mykiss) from Poland
}

\author{
Leszek Guz, Krzysztof Puk
}

Received - 14 July 2020/Accepted - 04 December 2020. Published online: 31 December 2020; Inland Fisheries Institute in Olsztyn, Poland Citation: Guz L., Puk K. 2020 - Molecular detection of Renibacterium salmoninarum in rainbow trout (Oncorhynchus mykiss) from Poland Fish. Aquat. Life 28: 234-237

\begin{abstract}
Renibacterium salmoninarum causes bacterial kidney disease mainly in salmonid fish. Oligonucleotide primers incorporating $R$. salmoninarum unique sequences were designed to amplify a $501 \mathrm{bp}$ region of the gene encoding a $57 \mathrm{kDa}$ soluble extra-cellular protein. The primers did not amplify other wide varieties of aquatic or piscine bacteria Aeromonas salmonicida or Yersinia ruckeri. This assay provides a molecular description and definitive identification of $R$. salmoninarum in Poland.
\end{abstract}

Keywords: Renibacterium salmoninarum, fish, bacterial kidney disease, infection

Renibacterium salmoninarum is a small, $G(+)$, rod-shaped bacterium that causes bacterial kidney disease (BKD) mainly in salmonid species such as sockeye salmon, Oncorhynchus nerka (Walbaum), rainbow trout, $O$. mykiss (Walbaum), chinook salmon, O. tshawytscha (Walbaum), coho salmon, O. kisutch (Walbaum), cutthroat trout, O. clarkii (Richardson), masou salmon, O. masou (Brevoort), pink salmon, O. garbuscha (Walbaum), Danube salmon, Hucho hucho (L.), grayling, Thymallus thymallus (L.), brook trout, Salvelinus fontinalis (Mitchill), Atlantic salmon, Salmo salar L., brown trout, Salmo trutta L., and in non-salmonid species

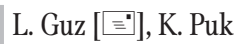

Department of Fish Diseases and Biology, University of Life Sciences, 20-950 Lublin, Poland

e-mail: leszek.guz@up.lublin.pl such as ayu, Plecoglossus altivelis (Temminck and Schlegel), burbot, Lota lota (L.), Pacific herring, Clupea pallasii Val., and sea lamprey, Petromyzon marinus L., in both freshwater and seawater environments (Eissa et al. 2006). Because a non-salmonid reservoir has not been identified, $R$. salmoninarum is currently considered an obligate pathogen of salmonids. The bacterium can be horizontally and vertically transmitted, and the disease is reported in many regions and countries worldwide including North and South America, Japan, and Europe (i.e., England, Denmark, Norway, France, Germany, and Poland) (Antychowicz and Grawiński 1994, Kozińska et al. 2001, Jansson 2002, Pękala-Safińska et al. 2017, Terech-Majewska et al. 2017).

Fish harboring $R$. salmoninarum can display various internal and external signs of the disease such as exophthalmia, skin blebs, cavitations in the musculature, distended abdomen, hemorrhagic areas in the skin, swollen kidney, and grayish nodules in the kidney, spleen, and liver. BKD is diagnosed by a combination of culturing and serological methods (Antychowicz and Grawiński 1994, Kozińska et al. 2001, Kozińska and Pękala 2005). The use of PCR has been advocated as a specific and sensitive means of diagnosing BKD (Brown et al. 1994, McIntosh et al. 1996). Several PCR and RT (reverse transcription) - PCR methods have been developed for $R$. 
salmoninarum, most of which target the msa gene for amplification (McIntosh et al. 1996, Miriam et al. 1997, Vardić et al. 2007). A nested PCR detecting the $57-\mathrm{kDa}$ major soluble antigen (msa, p57) is recommended by the OIE for screening purposes (Chase and Pascho 1998, OIE 2006, Arnason et al. 2013, Pękala-Safińska et al. 2017).

The aim of this work was to confirm the presence of $R$. salmoninarum in rainbow trout with clinical signs of BKD by PCR assay. Additionally, sequence analysis of the PCR product was performed to characterize the bacterium.

The diseased, moribund rainbow trout $(n=32)$ $(60-150 \mathrm{~g})$ were transferred alive to the Department of Fish Diseases and Biology, Faculty of Veterinary Medicine, University of Life Sciences in Lublin, Poland, during the fall of 2016. All the fish were measured, weighed, and dissected. Samples of liver, spleen, and kidney were collected aseptically and samples were streaked on selective kidney disease medium (SKDM) and incubated at $16^{\circ} \mathrm{C}$ for 6 weeks. The characteristic lesions and growth of $R$. salmoninarum were verified by Gram-staining smears. The predominant colonies that grew on the agar plates were purified and stored at $-80^{\circ} \mathrm{C}$ after supplementation with $20 \%$ (v/v) glycerol.

$R$. salmoninarum was identified molecularly by isolating total DNA from freshly grown culture. DNA extraction was conducted using a Genomic Mini Kit according to the manufacturer's instruction (A\&A Biotechnology, Gdynia, Poland). The DNA was eluted with $200 \mu \mathrm{L}$ of TB Buffer heated to $70^{\circ} \mathrm{C}$. The samples were run immediately following elution.

The colonies were identified by amplifying a 501 bp region of the gene encoding a $57 \mathrm{kDa}$ soluble protein (p57) using primers Rs1 (5'-CAAGGTGAAGGGAATTCTTCCACT-3') and
Rs2 (5'-GACGGCAATGTCCGTTCCCGGTTT-3') (Brown et al. 1994). PCR reactions were performed in a thermal cycler (MJ-Mini, Bio-Rad, Warsaw, Poland) with the following amplification profile: initial denaturation at $94^{\circ} \mathrm{C}$ for $10 \mathrm{~min}$, followed by $30 \mathrm{cy}-$ cles at $94^{\circ} \mathrm{C}$ denaturing for $1 \mathrm{~min}, 48^{\circ} \mathrm{C}$ annealing for $1 \mathrm{~min}, 72^{\circ} \mathrm{C}$ extending for $1 \mathrm{~min}$, and a final extension at $72^{\circ} \mathrm{C}$ for $5 \mathrm{~min}$. To test the specificity and cross-reactivity of the PCR test, two other bacteria, Aeromonas salmonicida and Yersinia ruckeri, were tested. The PCR products were analyzed at a constant voltage of $7 \mathrm{~V} \mathrm{~cm}^{-1}$ on $1 \%$ agarose gel containing $\left(0.005 \mu \mathrm{L} \mathrm{mL}^{-1}\right)$ Midori Green Advanced DNA Stain (Nippon Genetics, Tokyo, Japan) and DNA Marker 1 (A\&A Biotechnology, Gdynia, Poland). DNA fragments of the expected length were purified using a Gel-Out Extraction Kit (A\&A Biotechnology, Gdynia, Poland) according to the manufacturer's instructions and subjected to direct sequencing at a DNA sequencing core facility (Genomed). Bacterial identity was deduced by a BLAST search to ascertain its closest related sequences.

$R$. salmoninarum is a well-known intracellular pathogen and is capable of surviving and multiplying in the cytoplasm of infected macrophages (Gutenberger 1993, McIntosh et al. 1996) and salmonid eggs (Brown et al. 1994). In the present study, the BKD diagnosis was made by macroscopic, light microscopy, bacterial culture, and PCR (Table 1). The fish exhibited weak external clinical signs of bacterial disease, such as loss of appetite, lethargy, dark coloration, exophthalmia, and distended abdomen (Fig. 1A). The most obvious internal signs were swollen kidney and/or liver and greyish nodules in the kidney (Fig. 1B, Table 1). Samples were collected from the kidneys by scraping them with a scalpel blade. The material collected was examined as

Table 1

Prevalence and testing for bacterial kidney disease (BKD) in rainbow trout (O. mykiss)

\begin{tabular}{|c|c|c|c|c|}
\hline Examined fish & Prevalence & Light microscopy & $\begin{array}{l}\text { Positive culture fish } \\
\text { pooled kidney samples }\end{array}$ & Positive PCR \\
\hline With kidney lesions & $20 / 32(62.5 \%)$ & $18 / 32(56.2 \%)$ & $1 / 1$ & $1 / 1$ \\
\hline Without kidney lesions & $12 / 32(37.5 \%)$ & 8/32 (25.0\%) & $1 / 1$ & $1 / 1$ \\
\hline
\end{tabular}



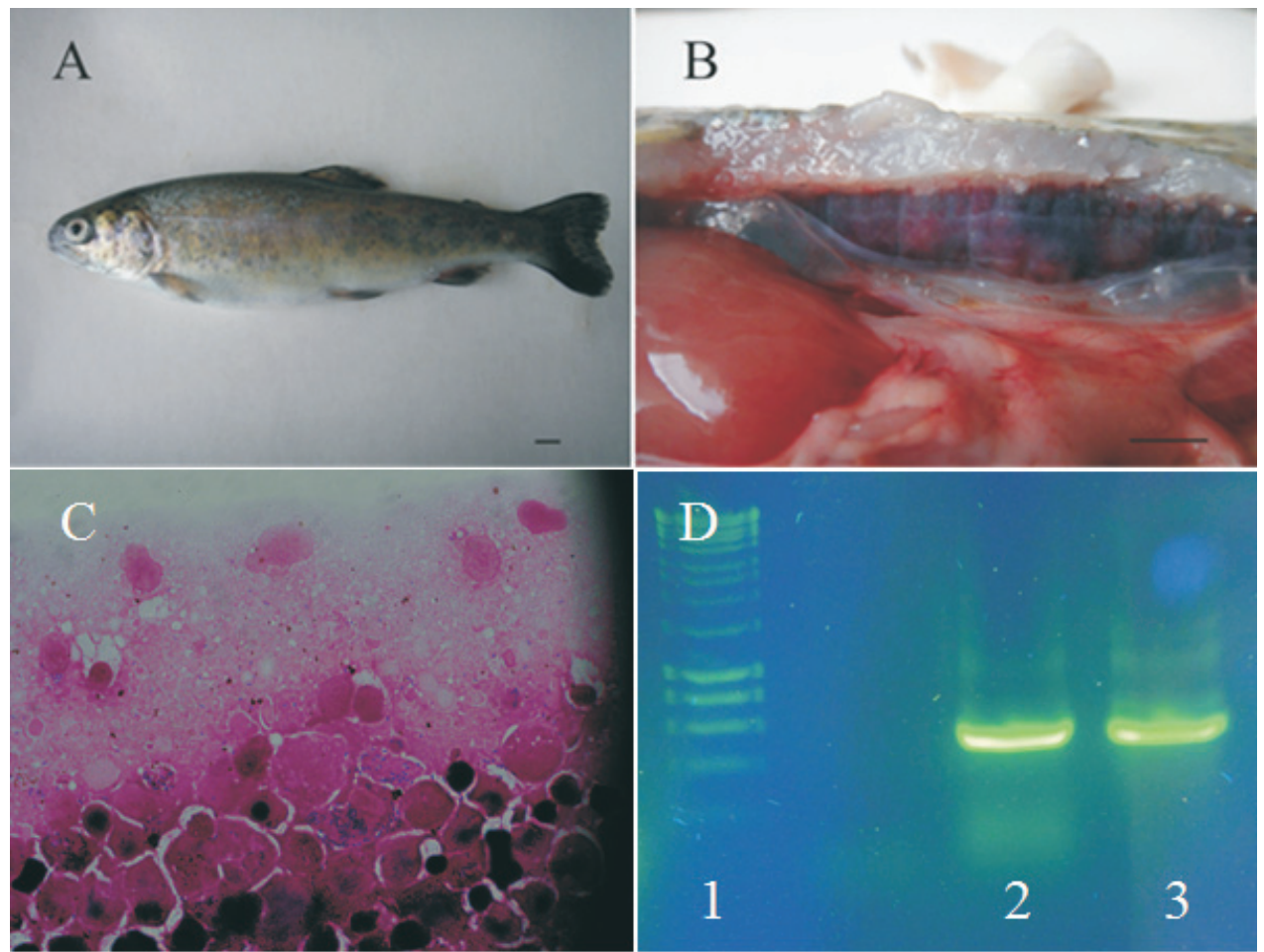

Figure 1. Rainbow trout with bacterial kidney diseases. Characteristic clinical signs observed: distended abdomen (A); enlarged kidney, grayish in color, with white nodular lesions (B); R. salmoninarum in kidney macrophages - Gram staining (C). Electrophoregram of $1.5 \%$ agarose gel stained with Midori Green Advanced DNA Stain showing amplification of the gene encoding a $57 \mathrm{kDa}$ soluble protein (primers Rs1/Rs2). Lane 1, DNA Marker 1. Lane 2, R. salmoninarum DNA isolated from kidney with lesions, and 3, R. salmoninarum DNA isolated from kidney without lesions (D).

a wet-mount preparation using a compound microscope, and $R$. salmoninarum was noted in the macrophages (Fig. 1C, Table 1). Isolated colonies of bacteria were creamy, shiny, smooth, round, raised, and $2 \mathrm{~mm}$ in size on SKDM agar after 6 weeks of incubation at $16^{\circ} \mathrm{C}$. Cells were Gram-positive and non-motile diplobacilli.

A fragment of the appropriate size $(501 \mathrm{pb})$ was amplified from DNA extracted from $R$. salmoninarum grown in agar culture (Fig. 1D, Table 1). All positions containing missing data were eliminated. There was a total of 401 positions in the final dataset. Evolutionary analysis was conducted in the MEGA6 program. The sequence $p 57$ gene of the clinical isolate of $R$. salmoninarum was deposited in the National Centre for Biotechnology Information Gene Bank database under accession number KU863577.

This study described a simple, DNA-based identification method of $R$. salmoninarum isolated from diseased rainbow trout in Poland.

\section{ORCID ID}

Leszek Guz iD http://orcid.org/0000-0003-4978-5577

\section{References}

Antychowicz J., Grawiński E. 1994 - Bacterial kidney disease in salmonid fish - Życie Wet. 69: 209-212 (in Polish).

Arnason I.Ö., Sigurdardottir S., Kristmundsson A., Svansson V., Gudmundsdottir S. 2013 - Evaluation of a semi-nested PCR for detection of Renibacterium salmoninarum in samples from kidney, gill and ovarian fluid of Atlantic salmon broodfish - Icel. Agri. Sci. 26: 49-57.

Brown L.L., Iwama G.K., Evelyn T.P.T., Nelson W.S., Levine R.P. 1994 - Use of the polymerase chain reaction (PCR) to detect DNA from Renibacterium salmumoninarum within individual salmonid eggs - Dis. Aquat. Org. 18: 165-171.

Chase D.M., Pascho R.J. 1998 - Development of a nested polymerase chain reaction for amplification of a sequence of the p57 gene of Renibacterium salmoninarum that provides a highly sensitive method for 
detection of the bacterium in salmonid kidney - Dis. Aquat. Org. 34: 223-229.

Eissa A.E., Elsayed E.E., McDonald R., Faisal M. 2006 - First record of Renibacterium salmoninarum in the sea lamprey (Petromyzon marinus) - J. Wild. Dis. 42: 556-560.

Kozińska A., Mazur W., Paszowska K. 2001 - Cases of bacterial kidney disease in brook trout in Poland - Med. Weter. 57: 273-275 (in Polish).

Kozińska A., Pękala A. 2005 - Investigating and evaluating the ELISA test in detecting Renibacterium salmoninarum in salmonid fish - Med. Weter. 61: 687-690 (in Polish).

McIntosh D., Meaden P.G., Austin B. 1996 - A simplified PCR-based method for the detection of Renibacterium salmoninarum utilizing preparations of rainbow trout (Oncorhynchus mykis, Walbaum) lymphocytes - Appl. Environ. Microbiol. 62: 3929-3932.

Miriam A., Griffiths S.G., Lovely J.E., Lynch W.H. 1997 - PCR and probe-PCR assays to monitor broodstock Atlantic salmon (Salmo salar L.) ovarian fluid and kidney tissue for presence of DNA of the fish pathogen Renibacterium salmoninarum - J. Clin. Microbiol. 35: 1322-1326.

Pękala-Safińska A., Głowacka H., Paździor E., Więcek B. 2017 - Pathology of kidney disease of salmonids - bacterial and superficial kidney disease - In: Proc. $42^{\text {nd }}$ Annual Conference of Trout Producers in Poland, 5-6 October 2017, Gdynia: 134-145 (in Polish).

Terech-Majewska E., Siwicki A.K., Deperasińska I., Schulz P., Bernad A., Duchiewicz K. 2017 - Bacterial kidney disease: current state of knowledge - Komun. Ryb. 158: 12-16 (in Polish).

Vardić I., Kapetanović D., Valić D., Kurtović B., Teskeredžćc Z., Teskeredñć E. 2007 - Detection of Renibacterium salmoninarum in tissue of brook trout (Salvelinus fontinalis) by nested RT-PCR - Ribarstvo 65: 15-24. 